\title{
Relationship between Parenting style and self concept of adolescents
}

\author{
Mr. J. P Badgujar*, Dr. Nisha Mundada**
}

\section{ABSTRACT}

The present study analyzed relationship between the Parenting Style and self concept of 400 VIII and X Standard students from Pachora in Maharashtra state (India). Bharadwaj et all's Parenting scale and Dr. Mrs. G. P. Sherry et all's self-concept scale is used. Majority of the adolescents have developed acceptance Parenting style on the models of Parenting. It is found that an average self-concept of adolescents is 56 percent.

Keywords: Parenting style, self-concept.

\section{INTRODUCTION}

Family is considered as the smallest social unit and the main element of each society. Family environment is the first and most important factor that influences the individual's growth (Bahrami, 2008). The foundation of development of individual lies in the womb of the family. The growth of child's personality depends upon the family atmosphere. Through family, he learns the norms of society, interrelationships and become a competent and useful member of society. Parents are supposed to create a most congenial, happy, democratic, lucid and warm atmosphere through their parenting style and through this child develops his hidden potentialities and social interaction skill. (Bharadwaj,1995).

If the children can't enjoy a good relationship with significant adults in their life, they will be negatively affected especially in their self shaping process. There are three ways children can be affected by the emotion that is being shown by their parents. First is when rejection happens. Second is when the parents become overprotected and third is when emotional confusion occurs as the result of the parents keep showing negative and positive emotions towards them one after another ( Barret \& Trent, 1991).

*Research Students,

**Research Guide, (S. S. M. M. College, Pachora. Jalgaon North Maharashtra University, India)

(C) 2014 J. Badgujar, N. Mundada; licensee IJIP. This is an Open Access Research distributed under the terms of the Creative Commons Attribution License (http://creativecommons.org/licenses/by/2.0), which permits unrestricted use, distribution, and reproduction in any Medium, provided the original work is properly cited. 
Generally in India both father and mother pay attention to the development of child but mother's role is more important especially middle class parents are more callous about their child's overall growth. Parents give more attention to their educational career. Nowadays, parenting style certainly is an interesting and important topic (Caporella, 2007). Aim of this present study is to increase better understanding about different parenting approaches bring different effectiveness in development especially self-concept among High school students.

\subsection{Parenting Style:}

Parenting is a complex activity that includes many specific behaviors that work individually and together to influence children out comes. The two distinctive roles of parent include both mothering and fathering. Loving, caring, authoritative fathering develop the child independent, emotionally stable and create his attitude positive towards the society. If mother's expectation is realistic, loving, caring less punishing and dominance the development of child is more productive and imaginative but utopian expectation of mother, over protection, more disciplined mother's behavior seen to be responsible for the problem of modes of parenting.

\subsection{Self - concept:}

Adolescent's self-concept is built on limited experiences and it is hard for him to relate himself to change social world. Self-concept is formed through experiences with the environment and is influenced especially by home environment reinforcements and significant others. (Shavelson et al, 1982)

The self has been defined as that part of one's personality of which one is aware. Self-concept is "the set of perceptions or reference points that the subject has about himself; the set of characteristics, attributes, qualities and deficiencies, capacities and limits, values and relationships that the subject knows to be descriptive of himself and which he perceives as data concerning his identity" (Hamachek, 1981; Machargo, 1991).

\section{REVIEW OF LITERATURE:}

Marfatia (1973) found that lack of parental love, over strictness or over disciplined, attitude especially that of father, constant quarrel between the parents, alcoholic parents, low family income, loneliness and lack of recreational outlet are some of the causes responsible for maladjustment among the adolescents in various areas home, emotional and school. Block (1985) found that child who experiences the psychological pain of parental rejection tends to manifest signs of maladjustment. Kurdeket al. (1994) found that adolescents raised in authoritative families are more socially competent, more self reliant and have a better work ethic. They also show power sign of psychological distress, such as anxiety or depression and fewer adjustment problems.

\section{METHODOLOGY}




\section{Aim of the Study:}

The study intends to measure the parenting style and self-concept of secondary school students and to find out the status and importance of parenting style in development of their self-concept.

\section{Hypotheses:}

In the present research work, following hypotheses are formulated,

1. Status of perceived parenting style among the adolescents.

2. Status of perceived self-concept among the adolescents.

3. There is significant relationship between each model of parenting and self- concept.

4. Contribution of parenting style in the development of self-concept.

\section{Sample:}

The study was conducted in Pachora, Jalgaon District of Maharashtra. Six Schools are selected randomly and 400 students have been enrolled from VIII to $\mathrm{X}^{\text {th }}$ standard in the sample.

\section{Tools:}

The following tools are used in the study.

\section{Parenting scale:}

Parenting scale developed and standardized by Bharadwaj, Sharma and Garg (1998) consists of eight models of parenting, with mothering, fathering and parenting status.

1) Rejection vs. Acceptance ( $R$ vs $A), 2)$ Carelessness vs. Protection(C vs $P)$, 3) Neglect vs. Indulgence(N vs I), 4) Utopian expectation vs. Realism(U vs R), 5) Lenient standard vs. Moralism (L vs M), 6) Freedom vs. Discipline(F vs D), 7) Faulty role Expectation vs. Realistic role Expectation (F vs R), 8) Marital conflict vs. Marital adjustment.(M vs M).

\section{Swatva Bodh Parikshan (SBP):}

This scale is constructed and standardized by Dr. Mrs. G. P. Sherry, Dr. R. P. Varma and Dr. P. K. Goswami. This scale consists of 48 items and 08 dimensions of self concepts.

\section{RESULTS AND DISCUSSION:}

The results and discussion of present study is as follows: 


\subsection{Status of each of the perceived model of parenting among the Adolescents:}

To identity the status of perceived model of parenting among adolescents they are classified on the sten score. The sten scores range from 1-10. The sten score 1-5 indicates lower score and 6-10 indicates higher score, the lower score means undesirable and negative dimension and higher score means desirable and positive dimension of the model of parenting.

Table I: Status of each of the perceived model of parenting among the Adolescents.

\begin{tabular}{|c|c|c|c|c|c|c|c|c|c|c|c|c|c|c|c|c|}
\hline \multirow{2}{*}{$\begin{array}{c}\text { Model } \\
\text { of parenting }\end{array}$} & \multicolumn{2}{|c|}{ R vs A } & \multicolumn{2}{|c|}{ C vs P } & \multicolumn{2}{|c|}{ N vs I } & \multicolumn{2}{|c|}{ U vs R } & \multicolumn{2}{|c|}{ L vs M } & \multicolumn{2}{|c|}{ F vs D } & \multicolumn{2}{|c|}{ F vs R } & \multicolumn{2}{|c|}{ M vs M } \\
\hline & Low & High & Low & High & Low & High & Low & High & Low & High & Low & High & Low & High & Low & High \\
\hline $\begin{array}{c}\text { Total } \\
\text { Student }(400)\end{array}$ & 28 & 372 & 215 & 185 & 126 & 274 & 19 & 381 & 124 & 276 & 94 & 306 & 81 & 319 & 71 & 329 \\
\hline Percentage & 0.7 & 93 & 53.75 & 46.25 & 31.5 & 68.5 & 4.75 & 95.25 & 31 & 69 & 23.5 & 76.5 & 20.25 & 79.75 & 17.75 & 82.25 \\
\hline
\end{tabular}

Status of Parenting style

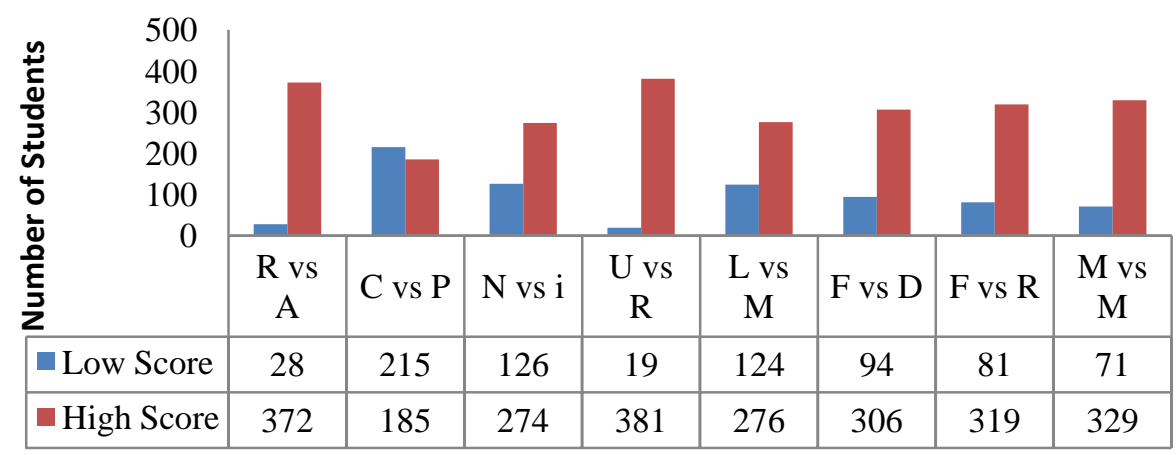

\section{Parenting style}

The results of the table I indicates that under Rejection Vs. Acceptance model of parenting 93 percent adolescents have perceived their parents have expressed acceptance in their interpersonal relationship. In second model i.e. Carelessness vs. Protection 46.25 percent adolescents has perceived carelessness that their parents do not pay adequate heed towards their activities that gives them an impression of unwantedness. On the third model Neglect Vs Indulgence 68.50 percent adolescents have perceived that parents give attention to their demands. But over indulgence of parents with the child develops certain whims and psychological inconsistencies in the latter. However, it should be kept open to us that indulgence with the child to a reasonable degree is a health giving sign and it also health developing child's self-concept. On the fourth model, Utopian expectation Vs Realistic expectation 95.2 percent adolescents have perceived that their parents expect realistic expectation from them. These realistic views of parental attitude know the child's capabilities and outside world also. Therefore, they never expect very high unrealistic and imaging demands from their children. On the fifth model, Lenient standard Vs Moralism 69 percent adolescents have perceived their parental moralism. It would be an 
admirable exercise, if a child prone to inculcate a reasonable degree of moralism in his personality orientations.

On the sixth model, Freedom Vs Discipline 76.5 percent adolescents have perceived parental discipline in their interpersonal relationship. Of course, the discipline is strong need of social orientations but severe discipline is on part hamper the delight and liberty of the child which he wishes to obtain at every stage of life. The result of table I indicates that under Faulty role expectation Vs Realistic role expectation model of parenting 79.75 percent respondents perceived for the realistic role of expectation, from their parents. The children know for certain that their parents are alike and what is expected to them. The last model Marital conflict Vs Marital adjustment 82.25 percent adolescents perceived that their parents' marital adjustment is good. Marital adjustment exhibits itself in a calm and composed adjustment between the parents thereby creating a solidarity and congenial atmosphere of peace and harmony in the family.

4.2 Status of self-concept among the Adolescents. -The status of the adolescents on self- concept is identified on the basis of the manual.

\begin{tabular}{|l|c|c|c|c|c|}
\hline $\begin{array}{c}\text { Row } \\
\text { Score }\end{array}$ & 20and less & $21-26$ & $27-38$ & $39-44$ & 45and above \\
\hline Category & $\begin{array}{c}\text { Very poor } \\
\text { self-concept }\end{array}$ & $\begin{array}{c}\text { poor self- } \\
\text { concept }\end{array}$ & $\begin{array}{c}\text { Average self } \\
\text { concept }\end{array}$ & $\begin{array}{c}\text { Good self- } \\
\text { concept }\end{array}$ & $\begin{array}{c}\text { Very Good self- } \\
\text { concept }\end{array}$ \\
\hline
\end{tabular}

The total score on the scale indicates the self-concept, whereas the greater the total score on the scale is expressed in terms of average self-concept.

Table II Status on the self -concept among the Adolescents.

\begin{tabular}{|l|c|c|c|c|c|}
\hline & $\begin{array}{l}\text { Very poor self } \\
\text { concept }\end{array}$ & $\begin{array}{l}\text { Poor self- } \\
\text { concept }\end{array}$ & $\begin{array}{l}\text { Average Self- } \\
\text { concept }\end{array}$ & $\begin{array}{l}\text { Good Self- } \\
\text { concept }\end{array}$ & $\begin{array}{l}\text { Very Good Self- } \\
\text { concept }\end{array}$ \\
\hline $\begin{array}{l}\text { No. of } \\
\text { Students- } \\
400\end{array}$ & 03 & 33 & 224 & 123 & 17 \\
\hline Percentage & 0.75 & 8.25 & 56 & 30.75 & 4.25 \\
\hline
\end{tabular}

The nature of self-concept is such that it is possible to enhance the overall success in one's life. Results indicate that 56 percent adolescents have Average self-concept, 30.75 Good self-concept, 8.25 percents Poor self-concept, 4.25 Very Good self-concept and 0.75 Very Poor self-concept. These results are concluded that the majority of the adolescents have developed average status of self-concept. It means that very few adolescents have developed lower level of status on Poor self-concept. Very few adolescents have developed lower level of status on Very Good selfconcept. Therefore, the second hypothesis that the majority of the adolescents have developed the statues of self-concept is average. 


\subsection{Relationship between the each perceived model of parenting and self-concept.}

The result of the table III critically reveals that the coefficient of correlation between selfconcept and all model of parenting style.

III Relationship between each perceived model of parenting style and self-concept.

\begin{tabular}{|c|c|c|c|c|c|c|c|c|c|c|}
\hline \multicolumn{10}{|c|}{ SBP and Parenting style Correlations } \\
\hline & & SBP & R vs A & C vs P & N vs I & U vs R & L vs M & F vs D & F vs R & M vs M \\
\hline \multirow{2}{*}{ SBP } & $\begin{array}{c}\text { Pearson } \\
\text { Correlation }\end{array}$ & 1 & $.179^{* *}$ & -.020 & -.007 & $.229^{* *}$ & $.322^{* *}$ & $.175^{* *}$ & $.305^{* *}$ & $.143^{* *}$ \\
\cline { 2 - 11 } & Sig. (2tailed) & & .000 & .692 & .887 & .000 & .000 & .000 & .000 & .004 \\
\cline { 2 - 11 } & N & 400 & 400 & 400 & 400 & 400 & 400 & 400 & 400 & 400 \\
\hline
\end{tabular}

**. Correlation is significant at the 0.01 level (2-tailed).

*. Correlation is significant at the 0.05 level (2-tailed).

The results from the table III exhibites that there exist significant correlations at both 0.1 and 0.5 significant levels, of self-concept and eight model of parenting style of the sample. The significant correlations between Rejection Vs Acceptance parenting style, Utopian Expectation Vs Realism parenting style, Lenient Standard Vs Moralism parenting style, Freedom Vs Discipline parenting style, Faulty role expectation Vs Realistic role expectation parenting style, Marital conflict Vs Marital Adjustment parenting style and self-concept.

Table IV Step wise regression Analysis model of parenting on self concept.

\subsection{Coefficient of SBP and Parenting Style}

\begin{tabular}{|l|c|c|c|c|c|c|c|c|}
\hline $\begin{array}{l}\text { Model of } \\
\text { parenting }\end{array}$ & R vs A & C vs P & N vs I & U vs R & L vs M & F vs D & F vs R & M vs M \\
\hline Beta & .102 & -.127 & -.217 & .194 & .270 & .062 & .223 & .041 \\
\hline
\end{tabular}

a. Dependent Variable: SBP

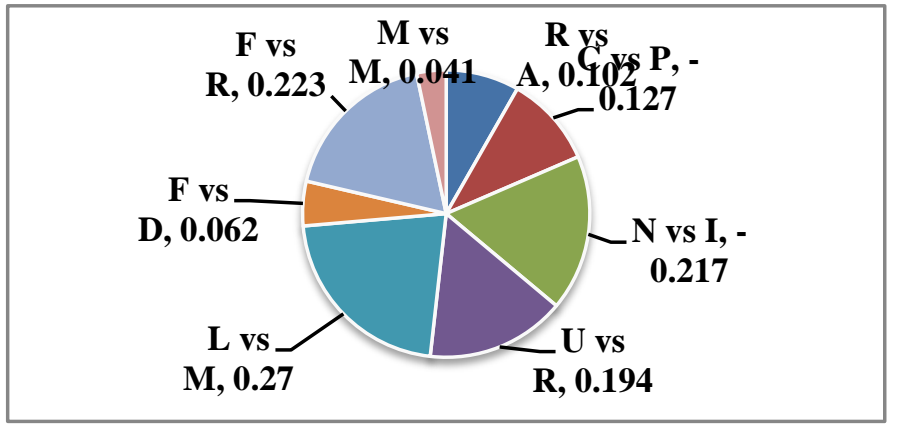

Table IV and graph reveals the step wise regression of the models of parenting on self-concept. The results indicates that Neglect Vs Indulgence ( $\mathrm{N}$ vs I), Lenient Standard Vs Moralism ( L vs M), Faulty role expectation Vs Realistic role expectation ( $\mathrm{F}$ vs R), models of parenting contributes more for the development of self-concept. 
From the above results, it is concluded that children with low parenting have unsatisfactory self-concept than children with high parenting style. Innovative programs on parenting may be planned to improve parent-child relationship during adolescence and help for better self-concept in adolescent age.

\section{REFERENCES:}

1. Bharadwaj, R.L., Sharma, H. and Garg, A(1998) A Manual of Parenting scale. Agra, Pankaj Mapan. Print.

2. Brian .C.C - How to use SPSS, $2^{\text {nd }}$ Ed.

3. Erikson, E.U.(1963) parents who cares more or less. journal of parents and children. Summer vol. XII No2. Print.

4. In J. Barooah, S. \& Phukan, M. (1999). A comparative study of self-concept of orphan. Print.

5. Kothari C.R. (2004): Research Methodology, New Age International Publisher.

6. Mangal .S.K. - Statistics in psychology and education, $2^{\text {nd }}$ Ed.

7. Marsh, H. W. (1993). Academic self-concept: Theory measurement and research. Print.

8. Minium, E. King, B.; Bear, G.(2008) Statistical Reasoning in psychology and Education, $3^{\text {rd }}$ Edi. Published by John Wiley \& Sons Inc. Print.

9. Tiwari, Savita \& Bansal, Indu.(1994). A study of self-concept of high and low achieving adolescent girls. Indian Psychological Review, 43, 21-25. Print 